$\stackrel{\circ}{\|}$

\title{
LUDZKA TOŻSAMOŚĆ WOBEC EKOKOLONIALIZMU
}

\begin{abstract}
Hanna Mamzer, Ludzka tożsamość wobec ekokolonializmu [Human Identity and Eco-colonialism] edited by E. Smolarkiewicz, J. Kubera, "Człowiek i Społeczeństwo" vol. XLIV: Tożsamość i identyfikacje. Propozycje teoretyczne - doświadczenia badawcze [Identity and identifications. Theoretical proposals - research experiences], Poznań 2017, pp. 49-64, Adam Mickiewicz University. Faculty of Social Sciences Press. ISSN 0239-3271.
\end{abstract}

Contemporary reality of everyday functioning of postmodern humans, provokes deep changes in thinking of human identities and human relations it natural and cultural surroundings. Human sciences have to confront the fact, that it is no longer possible to divide human identities from those of non-humans. The connections between human and non-humans are clear and significant, and they are reflected on by the most prominent thinkers in the fields of social sciences (W. Kymlicka) and ecology (E.O. Wilson), at the same time. Understanding human identity requires connecting it with is natural surrounding, again. And this surrounding shall not be divided into "natural" and "cultural" ones anymore. Clarity of such divisions is seriously questioned by impossibility of drawing clear border lines between them. Such thinking creates new context for understanding humans. And this requires new tools as well: therefore it becomes very clear that humanities/social sciences and real science need to speak one voice.

Hanna Mamzer, Uniwersytet im. Adama Mickiewicza w Poznaniu, Instytut Socjologii, ul. Szamarzewskiego 89c, 60-658 Poznań, e-mail: mamzer@amu.edu.pl

W niniejszym tekście, proponuję zrewidować dwa utarte schematy myślenia o tożsamości podmiotu.

Po pierwsze, już na dobre przyjęło się, nie tylko w polskiej humanistyce i naukach społecznych, by pisać o tożsamości indywidualnej lub zbiorowej w różnych odsłonach, ale tylko odnośnie do tożsamości ludzkiej, traktowanej jako oderwana od otoczenia przyrodniczego, w zamian osadzona 
w kontekście kulturowym. W tym sensie tożsamość podmiotu ludzkiego stała się niejako fenomenem, opisywanym jedynie w odniesieniu do człowieka postawionego na piedestale antropocentryzmu, nienawiązującego w żaden sposób do tożsamości innych, nie-ludzkich podmiotów. Taka refleksja nad ludzką tożsamością dominowała w humanistyce polskiej przez ostatnie kilkanaście lat ${ }^{1}$. Bezsprzecznie wynika to ze społeczno-kulturowego kontekstu polskiego społeczeństwa, osadzonego w realiach przechodzenia z systemu totalitarnego do systemu demokratycznego; z kulturowej izolacji do kontaktu z odmiennością kulturową; z koncentracji na grupowym myśleniu do myślenia w kategoriach ,ja” oraz z życia w świecie zdominowanym przez zewnętrznie lokalizowane poczucie kontroli do życia, w którym dominuje uwewnętrznienie tegoż poczucia. W takich warunkach konieczny był szczególny namysł nad tożsamościami zbiorowymi, ale co za tym idzie - także nad tożsamościami autonomizujących się jednostek, funkcjonujących w globalizującym się świecie. Poszukiwania poznawcze związane ze specyfiką tożsamości społecznych (kulturowych, etnicznych, grupowych itd.) zmierzały do udzielenia odpowiedzi na pytania: Jak wyodrębnić tożsamość grupy z większej społeczności, by jej nie alienować? Jak budować relacje z nowo powstającymi autonomicznymi społecznościami, które dotąd jako takie nie istniały?2 Jak zachować swoją tożsamość przy wchodzeniu w większe struktury? Z jakich elementów tożsamościowych można zrezygnować, a jakie trzeba utrzymać, by nie mieć poczucia zatracenia własnego społecznego ja? ${ }^{3}$ Wreszcie: jak zachować swoją unikatowość w unifikującym procesie globalizacji? Widać wyraźnie, że te wszystkie dylematy miały związek z dynamicznymi procesami społeczno-politycznymi przełomu XX i XXI w. Na poziomie tożsamości jednostkowych najważniejsze stawiane pytania przyjmowały postać następującą: Czy jednostka przejmuje tożsamość od innych ludzi, czy tworzy ją ${ }^{4} \mathrm{Z}$ jakich elementów tę indywidualną tożsamość budować?

${ }^{1}$ Kiedy w 2002 r. publikowałam Tożsamość w podróży, refleksja polskiej humanistyki w tym zakresie była nader skromna. Ograniczała się do ponowoczesnych wzorów osobowych Zygmunta Baumana (por. 1993) i psychoanalitycznie zorientowanych prac nawiązujących do E.H. Eriksona (por. 2004).

${ }^{2} \mathrm{~W}$ odniesieniu do rozpadu starych, dużych struktur państwowych w rodzaju ZSSR czy Jugosławii.

${ }^{3}$ Szczególnie w kontekście włączania się poszczególnych państw do Unii Europejskiej.

${ }^{4}$ Dylemat związany z widocznym przeskokiem z trybu działania społeczeństw kolektywnych (wymuszonego przez komunizm), w których - jak w społeczeństwach tradycyjnych - tożsamość jednostki była odzwierciedleniem tożsamości społeczności oraz jej statusu w tejże społeczności. Podobnie rzecz ujmowali symboliczni interakcjoniści czy w ramach antropologii Margaret Mead 1978 - pisząca o społecznościach postfiguratyw- 
Kiedy jej tworzenie się kończy? Czy można ją modyfikować, a jeśli tak, to jak dalece wolno w nią ingerować? ${ }^{5}$ Wszystkie te dylematy były bezpośrednim odzwierciedleniem procesów psychospołecznych zachodniej rzeczywistości kulturowej. Stopniowo wymusiły one stawianie pytań o moralność i granice etyki w procesach związanych z tworzeniem i modyfikowaniem tożsamości. Na metapoziomie refleksji nad tożsamością wymuszały też wprowadzenie pewnych pytań porządkujących: Jak klasyfikować tożsamości? Czy można je jakoś dzielić? Jakie zachodzą między nimi związki?

Drugi schemat myślenia o tożsamości zawdzięczamy wspomnianej wcześniej globalizacji i temu, że w świecie mobilnych ludzi zakorzenienie w miejscu stało się rzadkością, a wręcz stanem ocenianym jako passe. Jak pisał Zygmunt Bauman (2000), udział w globalizacji oznacza mobilność. Osoby niemające możliwości, by się przemieszczać, podróżować, zmieniać społeczne i kulturowe konteksty, migrować pomiędzy warstwami stratyfikacyjnymi społeczności, nie są uczestnikami globalizacji i stają się społecznym marginesem przeznaczonym „na przemiał” (por. Bauman 2004b). Te tendencje popchnęły humanistów do myślenia o tym, że człowiekowi nie jest potrzebne osadzenie w jakimś konkretnym ulokowaniu przestrzennym, że podmiot ludzki może sobie bez tego doskonale radzić, utrzymując swoją tożsamość osadzoną przede wszystkim we własnych procesach psychicznych, stanowiących oparcie dla chwiejności otaczającego świata. Pisałam o tym w innym miejscu (2008), polemizując z koncepcją Anthony’ego Giddensa poczucia bezpieczeństwa ontologicznego, które to pojęcie formułował on tak, że nie mogło mieć odniesienia do sposobu działania społeczeństw ponowoczesnych, a jedynie do społeczeństw o charakterze społeczności tradycyjnych. Giddensowskie ujęcie poczucia bezpieczeństwa ontologicznego zakładało jego osadzenie w przewidywalności otoczenia i tego, co się w nim dzieje. Taka przewidywalność ma miejsce w społecznościach tradycyjnych, zmieniających się powoli, gdzie zmiana jest ewenementem, a nie normą,

nych. W społeczeństwach prefiguratywnych (według typologii Mead), zwanych najczęściej ponowoczesnymi, tożsamość indywidualna stała się „,zadaniem do wykonania”, co podkreślali jednym głosem Zygmunt Bauman (2004a) i Anthony Giddens (2002).

${ }^{5}$ Po przejściu od tożsamości nadanej do tożsamości tworzonej okazało się, że jej modyfikacje są w zasadzie nieograniczone - nie tylko na poziomie psychologicznym czy psychospołecznym. Wraz z dynamicznym rozwojem technologii, szczególnie medycznych, ingerowanie w warstwę somatyczną nie jest dużym wyzwaniem: powszechność operacji plastycznych (w tym także tych wchodzących w bardziej złożone procesy, jak modyfikacja płci) powoduje, że zniesione zostały granice autokreacji (por. eksperymenty artystyczne Orlan, http://www.orlan.eu/ [1.01.2018]. 
i gdzie wzorcem funkcjonowania ludzi jest przyroda ze swoją przewidywalnością. W społeczeństwach ponowoczesnych, skrajnie odmiennych, gdzie norma to zmiana, i to niesłychanie dynamiczna, nie ma możliwości budowania poczucia przewidywalności świata na otoczeniu zewnętrznym. Tym oparciem musi być wewnętrznie ulokowane przekonanie podmiotu o tym, że jego kompetencje i zdolność radzenia sobie ze zmiennością otoczenia są niezmiennym antidotum na jego nieprzewidywalność. To lokowanie poczucia bezpieczeństwa ontologicznego wewnątrz podmiotu, a w zasadzie w jego wewnętrznych zdolnościach i procesach psychicznych, wzmacniało myślenie o świecie w taki sposób, że wskazywało na to, iż człowiek może dobrze funkcjonować bez osadzenia w konkretnym miejscu, żee jego efektywność pragmatyczna oraz refleksyjna nie muszą być związane z fizycznie wyznaczonym miejscem.

Do myślenia o tożsamości człowieka jako oderwanej od miejsca zachęca także Jerzego Kmity (Banaszak i Kmita 1994) społeczno-regulacyjna koncepcja kultury. Według niej kultura stanowi rzeczywistość myślową złożoną z sądów normatywnych i dyrektywalnych respektowanych w danej społeczności. Ta niezwykle kusząca intelektualnie propozycja pozwala oderwać tożsamość od bezpośrednich powiązań z etnicznością czy narodowością. W dobie wszechogarniającej globalizacji takie myślenie o kulturze stało się bardzo atrakcyjne: przenosiło bowiem rozumienie kultury z odniesień do konkretnych artefaktów kulturowych, na poziom myślenia o wartościach i ich zachowaniowego respektowania. Można było w ten sposób mówić o kulturze jako o fenomenie pozwalającym na identyfikowanie się z nim także poza granicami kraju pochodzenia osoby. Można więc było mówić o tym, że przemieszczanie się w przestrzeni, zmiana miejsca życia czy długotrwałego pobytu nie musi wpływać na erozję poczucia przynależności do kultury pochodzenia, a co za tym idzie - identyfikacji kulturowej.

Dzisiaj obydwa te schematy myślenia o tożsamości podmiotu ludzkiego: jako tożsamości człowieka w ujęciu antropocentrycznym i tożsamości oderwanej od miejsca w przestrzeni, są przynajmniej osłabione. Można pokusić się o tezę bardziej radykalną, wymagającą poważnego namysłu. Zgłaszał to już Francis Fukuyama (1997), sugerując, że zagubiony w świecie zatomizowanych jednostek, prędzej czy później człowiek „ponowoczesny” będzie musiał się zwrócić ku małym społecznościom lokalnym, które dają oparcie, poczucie więzi i wspólnoty, a co za tym idzie - poczucie bezpieczeństwa. Wedle Fukuyamy miały one być też antidotum na unifikujący wpływ globalizacji, prowadzący do takiego stopnia homogenizacji kulturowej, która niszczy przekonanie podmiotu o jego unikatowości, 
sprawstwie i sensie podejmowania działań wskazujących na jednostkową wartość (choć i to samo można odnieść do poziomu funkcjonowania społeczności). Fukuyamy propozycja rozwijania społeczności lokalnych stała się proroczym wezwaniem do inwestowania w rozwój i umacnianie relacji międzyludzkich, opartych na bezpośredniości (umownej) i odnoszących się do konkretnych innych podmiotów oraz do miejsca. Spodziewam się, że niewielu, podejmując refleksję nad propozycją Fukuyamy, widziało w niej zapowiedź rozwoju lokalnych społeczności w takim wymiarze, jaki jest dziś w Polsce widoczny. To właśnie małe społeczności stanowią dzisiaj przeciwwagę dla działań i procesów o charakterze „głównego nurtu”6. Widać dziś w polskim społeczeństwie narastający ruch małych stowarzyszeń, reprezentujących społeczności lokalne i ich interesy ${ }^{7}$, przeciwstawiających się skutecznie odgórnie narzucanym rozwiązaniom.

O zagadnieniach związanych z tożsamością można myśleć wielopoziomowo: w bardzo konkretnym wymiarze odnoszącym się do rozstrzygnięć o charakterze niemal pragmatycznym (lub wprost pragmatycznym) aż do poziomu meta, gdzie samo pojęcie tożsamości jest ujmowane jako pretekst do rozważań o kondycji ludzkiej w otaczającym ją świecie. Odnosi się to zarówno do zakresu jednostkowego, indywidualnego, jak i społecznego, zbiorowego. Dlatego, po tym, jak humanistycznie zostały już opracowane wątki opisujące tożsamość ludzką w wymiarze jednostkowym oraz zbiorowym, warto dziś te ustalenia skonfrontować z trendami silnie wkraczającymi w humanistyczną refleksję nad istotą podmiotowości, a co za tym idzie - nad istotą tożsamości ludzkiej. Jednym z tych nurtów jest posthumanistyczne reflektowanie nad światem, na powrót łączące ludzi z ich otoczeniem biologicznym, modyfikującym, ale i integrującym już przyjęte sposoby myślenia o specyfice i roli podmiotów ludzkich.

We współczesnej refleksji na temat tożsamości ludzkiego podmiotu dopiero od niedawna podejmuje się rozważania nad posthumanistycznie zorientowanym konfrontowaniem tożsamości ludzi i nie-ludzi. Jest to podejście, którego nie sposób dłużej ignorować, bowiem humanistyczna

\footnotetext{
${ }^{6}$ Mam na myśli społeczne reakcje na zmiany polityczne i przez polityków wprowadzane modyfikacje procesów, instytucji i regulacji społecznych. Pisałam o tym (Mamzer 2016a; 2016b), podkreślając niestandardowe i twórcze zachowania społeczności lokalnych - zmierzające nawet w kierunku obywatelskiego nieposłuszeństwa w rozumieniu H.D. Thoreau (por. 2011).

${ }^{7}$ Przykładem takiej lokalnej aktywności może być wprowadzanie budżetów obywatelskich w Polsce - pierwszy został uchwalony w Sopocie w 2011 r. dzięki inspiracji Sopockiej Inicjatywy Rozwojowej, zob. http://budzetyobywatelskie.pl [28.12.2017].
} 
refleksja zmierza jednoznacznie ku równouprawnieniu podmiotów ludzkich i nie-ludzkich. W tym kontekście wymaga przywołania kanoniczna praca Sue Donaldson i Willa Kymlicki, zatytułowana Zoopolis (2011). Ta książka, mało znana w Polsce, w radykalny sposób zmienia myślenie o człowieku i jego relacjach z otoczeniem. Kymlicka, jako niekwestionowany autorytet w dziedzinie refleksji nad polityką wielokulturowości, orędownik wyrównywania deficytów w zakresie kapitału kulturowego mniejszości etnicznych (w szczególności Kanady), poprzez stwarzanie rządowo sankcjonowanych programów promujących politykę multikulturalizmu działał na rzecz sprawiedliwego traktowania grup mniejszościowych przez zastosowanie ram liberalizmu. Dwa podstawowe rodzaje mniejszości w jego ujęciu to grupy imigranckie (lub wielonarodowościowe) oraz mniejszości narodowe (jak na przykład Maorysi w Nowej Zelandii czy australijscy Aborygeni). Kryteria uznania społeczności za mniejszość narodową to: (1) jej obecność na terenie danego państwa przed powstaniem tego państwa (lub w momencie jego tworzenia - jako struktury administracyjnej); (2) samorządność tych grup etnicznych i historia ich suwerennego rządzenia; (3) wspólna kultura; (4) wspólny język; (5) zarządzanie społecznością poprzez stworzenie instytucji. Zastosowanie tych kryteriów pozwoliło myślicielowi na wyodrębnienie grup określanych mianem pierwszych narodów (first nations) oraz grup wieloetnicznych innego pochodzenia. Pierwsze narody zasługują na uzyskanie dostępu do wyjątkowych praw ze względu na ich kolosalną i niepowtarzalną rolę w tworzeniu tożsamości danego narodu jako całości. Grupy etniczne innego rodzaju, pojawiające się niejako na „własne życzenie” w danej większości, muszą się już dostosowywać do większości i prawa im należne powinny być mniejsze. Na nich też spoczywa odpowiedzialność zintegrowania się z większościową, dominującą grupą kulturową. Prawa im należne powinny być mniejsze niż te przysługujące pierwszym narodom, ale mimo wszystko powinny im przynależeć. W pracy z 1996 rr.oku Multicultural Citizenship Kymlicka dowodzi, że zasada przyznawania różnych praw różnym grupom ze względu na ich tożsamość jest spójna z założeniami liberalizmu i koresponduje z wartością, jaką są prawa obywatelskie. Główny powód, dla którego Kymicka podejmował w swoich poznawczych pracach tematykę równouprawnienia mniejszości etnicznych, było jego głębokie przekonanie o tym, że większości społeczne traktują grupy mniejszościowe w sposób wyzyskujący, wręcz eksploatujący. Szczególnie eksploatowane (aż do fizycznej eksterminacji) były/są first nations. Głęboka niezgoda filozofa na taki stan rzeczy sprowokowała go do podjęcia pracy intelektualnej zmierzającej do budowania i promowania polityki wielokulturowości, pomyślanej 
tak, by w jak najefektywniejszy sposób dokonać reperacji strat poniesionych przez pierwsze narody na skutek działań kolonizacyjno-eksploatacyjnych realizowanych przez dominujące kultury napływowe. Kwestie powiązań pomiędzy tożsamością jednostki i grupy, pomiędzy identyfikacjami a zróżnicowaniem kulturowym, przemieszczaniem (w sensie relokacji mniejszości) a przywiązaniem do miejsca, są tutaj bardzo czytelne.

Kontynuując wątek społecznie sankcjonowanego eksploatowania jednej kategorii społecznej przez inną, w 2011 r. wraz z Sue Donaldson Kymlicka podjął refleksję nad problemem statusu ostatniej, jego zdaniem, kategorii eksploatowanej we współczesnym świecie: zwierząt nie-ludzkich. W Zoopolis autorzy przyjmują (jak cały posthumanizm w ogóle), że ludzie są biologicznie związani ze swoją przeszłością ewolucyjną i nie można o nas mówić inaczej jak w kategoriach biologiczno-zwierzęcych. Nie ma to określenie ani funkcji dyskredytującej, ani pejoratywnej - przeciwnie, wskazuje na łączność człowieka z jego otoczeniem biologicznym oraz na powiązanie jego tożsamości z tożsamościami innych zwierząt. Donaldson i Kymlicka argumentują, że zwierzęta inne niż ludzie są przez ludzi bezprawnie zdominowane w sensie eksploatacyjnym. Po pierwsze, zostały zdefiniowane przez człowieka jako gatunki/nie-podmioty słabsze, gorsze, szkodliwe lub niższe. Po drugie, takie zdefiniowanie sankcjonuje realizowanie wobec nich zaawansowanych i rozbudowanych pragmatycznych praktyk eksploatacyjno-wyniszczających. Niezgoda autorów na takie podejście sprowokowała ich do realizacji swoistego eksperymentu myślowego, zmierzającego do intelektualnej próby skonstruowania świata, w którym zwierzętom przynależą prawa obywatelskie. Zwierzęta pozaludzkie bowiem, jak argumentują, nie weszły do świata ludzi dobrowolnie. Świat ludzi został im narzucony poprzez odebranie przestrzeni życiowej w drodze postępującej antropopresji oraz przez odebranie praw (porównywalne z procesem delegitymizacji, stanowiącym element łańcucha dyskryminacyjnego ${ }^{8}$ ). To pozwoliło ludziom na fizyczne eksterminowanie nie-ludzi ${ }^{9}$ służące konsumpcji w różnych formach. Dlatego też autorzy proponują wyróżnienie trzech typów zwierząt, którym to typom będą przyznane różne prawa. I tak: zwierzęta domowe powinny zyskać status

${ }^{8}$ W skład tego łańcucha wchodzą następujące procesy: emocjonalne dystansowanie się, dewaluacja, delegitymizacja (odebranie należnych praw), segregacja i eksterminacja. Pierwsze dwa etapy zachodzą w wewnętrznych procesach psychicznych człowieka. Etap trzeci stanowi przeniesienie efektów dwóch poprzednich etapów na poziom społeczny. Dwa ostatnie elementy to działania na poziomie działań społecznych.

${ }^{9}$ Choć do pewnego momentu historycznego także i ludzi, w formie niewolnictwa czy tzw. Human Zoo. 
współ-obywateli (co-citizenship), co wymusiłoby takie ich traktowanie, które bierze pod uwagę ich najlepszy interes i preferencje. Zwierzętom dzikim powinna przysługiwać suwerenność na ich własnym obszarze (rozumianym jako przestrzeń życiowa), co pozwoliłoby im na zachowanie gatunku, życie i prosperowanie pozwalające na przetrwanie. Gatunki tzw. graniczne (Liminal animals), zawieszone pomiędzy jedną a drugą kategorią (takie jak myszy, szczury, gołębie czy na przykład karaluchy), powinny być traktowane jako regularni mieszkańcy miast. Myślenie o takim traktowaniu zwierząt innych niż ludzie ma prowokować do refleksji na temat antropocentryzmu i jego dominacji wobec odmiennych form życia. Koncepcja Donaldson i Kymlicki jest rozbudowana i konfrontuje odbiorcę z radykalnymi tezami, którym jednak trudno odmówić racji, a które (wszystkie w zasadzie) wskazują na to, że hierarchia gatunków i stosunek do nich są ustalone i zdefiniowane przez człowieka, a nie stanowią obiektywnej prawdy o świecie.

„Zoopolis” jest eksperymentem myślowym podważającym dotychczasowy sposób myślenia o tożsamości i prawach człowieka oraz proponującym modyfikację obowiązujących umów społecznych, określających wzajemne relacje ludzi i nie-ludzi. Poprzez zarysowanie ekstremalnych możliwości wskazuje, że jest możliwy świat inny niż ten, w którym funkcjonuje człowiek początku XXI w. Idzie za tym inne myślenie o tożsamościach i inne myślenie o miejscach stanowiących zakorzenienie dla tych tożsamości. Tożsamości ludzkie i nie-ludzkie się tu łączą i tworzą jeden nowy (?) świat. Łączącym elementem, będącym przejściem pomiędzy etnicznymi mniejszościami a zwierzętami nie-ludzkimi, są praktyki eksploatacyjne i niezgoda na nią.

Podobny sposób myślenia widoczny jest także na gruncie nauk przyrodniczych, szczególnie ekologii, gdzie w wielu pracach promuje się dzisiaj jedność podmiotu i jego otoczenia, a co za tym idzie - jedność humanistyki i nauk przyrodniczych (por. Wilson 1984; 2016; 2017). Na metapoziomie zmienia to sposób myślenia o tożsamości ludzkiej, gdyż wskazuje jej łączność, a na pewno relacyjność z innymi podmiotami nie-ludzkimi. Celowo stosuję tutaj określenie szerokie: jako podmioty nie-ludzkie rozumieć należy bowiem nie tylko zwierzęta inne niż ludzie, ale też technologicznie zaawansowane maszyny w rodzaju robotów wyposażonych w sztuczną inteligencję. W posthumanistycznym myśleniu o miejscu człowieka w świecie te dwa odrębne wątki wskazują na dwie sprzeczne (?) tendencje zachodzące w rozwoju relacji człowieka i świata go otaczającego. Jedna z tych ścieżek wiedzie ku relacjom z maszynami (robotami, sztuczną inteligencją, nanostrukturami i innymi przykładami adaptowania technologii na poziom tworzenia relacji z ludźmi), co skutkuje oddzielaniem od świata przyrodniczego. 
Wątek drugi to wcześniej zarysowany wątek relacji ze zwierzętami pozaludzkimi, będący efektem opisywanej przez Edwarda O. Wilsona biofilii (1984).

Interesujący jest fakt, że można w tym zakresie zaobserwować swoiste fluktuacje. Wydaje się, że kwestie porównań tożsamości ludzi i tożsamości maszyn wcześniej przeniknęły do namysłu nauk społecznych niż porównywanie ludzi i innych zwierząt w celu definiowania ich tożsamości. W obliczu najnowszych osiągnięć myśli technicznej, które przyniosły konstrukcję robota Sophia (por. https://www.youtube.com/watch?v=S5t6K9iwcdw [1.01.2018]) wyposażonego w sztuczną inteligencję, znowu jednak do punktu centralnego wraca zagadnienie porównywania tożsamości ludzi i maszyn. Wymusza to tworzenie przez ludzi innych narracji o sobie. W tym kontekście wydaje się, że nawoływanie do konfrontowania ja ludzkiego z ja nie-ludzkim nie nadąża za rzeczywistością. Refleksja jest, jak się wydaje, w tyle za tym, co technicznie już możliwe. W dobie konstruowania robotów wyposażonych w sztuczną inteligencję, reagujących nie tylko na wypowiedzi werbalne człowieka, ale i na jego niewerbalne przekazy, konfrontowanie się z Innym zwierzęcym mogłoby być postrzegane jako krok w tył. Sophia robot najnowszej generacji, werbalizujący odpowiedzi, odczytujący mimikę i inne sygnały niewerbalne, otrzymał obywatelstwo Arabii Saudyjskiej, co sankcjonuje jego podmiotowość i stawia ją wyżej niż podmiotowość kobiet w tym kraju. Jak w takiej sytuacji w ogóle mówić jeszcze o aplikowaniu propozycji formułowanych przez filozofię dialogu na grunt porównań ludzko-nie-ludzkich? Wątek relacji tożsamości człowieka z maszynami jest niezwykle bogatym i inspirującym intelektualnie zagadnieniem, któremu należałoby się przyjrzeć w odrębnym tekście. Tutaj więc koncentruję się na relacjach tożsamościowych ludzi i nie-ludzi biologicznych, sądzę bowiem, że mamy obecnie do czynienia ze swego rodzaju dualizmem percepcji miejsca człowieka w świecie. Z jednej strony podmiot ludzki jest uczestnikiem dyskursu promującego biofobię, z drugiej strony podkreśla się związki człowieka z otoczeniem przyrodniczym w ramach biofilii (Wilson 1984).

Refleksja nad relacjami tożsamości ludzko-nie-ludzkich wiedzie prostą drogą ku propozycjom filozofii dialogu. Ta, wprowadzając pojęcie Innego, zarysowała konieczność konfrontowania się z odmiennością w celu doprecyzowania tożsamości własnej. W zasadzie, w tym nurcie myślenia, idee tożsamości własnej, konfrontacji z Innym, tożsamości Innego są odzwierciedleniem myślenia zorientowanego antropocentrycznie, w którym nawet nie dopuszcza się możliwości analizowania tych fenomenów u osób nie-ludzkich. W pracach filozofów tego nurtu nie znajdujemy także wątków 
wskazujących na możliwość myślenia o osobach nie-ludzkich jako nośnikach tożsamości własnej. Nie mówi się tam także o tym, że konfrontowanie się człowieka z nie-człowiekiem w zasadzie należałoby traktować jako kwintesencję porównań służących definiowaniu tego, czym/kim jako podmiot ludzki jest, a czym/kim nie jest. Przyznać należy, że nic nie stoi na przeszkodzie by podjąć taki oto eksperyment intelektualny, który zmierzałby ku zderzeniu ludzkiej tożsamości podmiotu z tożsamością nie-ludzką. Co więcej, okazuje się, że tego rodzaju eksperymenty przenoszone są już z płaszczyzny mentalnej, intelektualnej, na poziom eksperymentu w rozumieniu klasycznych nauk przyrodniczych.

Eksperymenty tego rodzaju, zmierzające do określenia granic ja człowieczego oraz możliwości przekroczenia tychże w celu poznania świata Innego, prowadzone są nie od dziś. Jedną z pierwszych tego rodzaju prób była ta opisana przez Johna Aleca Bakera - wcielenia się w życie sokołów wędrownych. Wyniki tego doświadczenia opublikowane zostały w $1967 \mathrm{r}$. w postaci książki zatytułowanej The Peregrine, choć sam eksperyment przeprowadzony został przez Bakera najprawdopodobniej kilka lat wcześniej. Przykładami podobnych, późniejszych eksperymentów poznawczych są: Farleya Mowata (1997) życie obok wilków (podejmował on także próby życia w stylu wilczym, w tym żywienia się tak jak wilki) oraz Martina L. Muellera (2017) analiza oddalenia się człowieka od przyrody poprzez opis relacji dwóch gatunków: człowieka i łososia. Wspomnieć też warto najnowsze doświadczenie Charlesa Fostera (2017) polegające na wnikaniu w świat przyrody poprzez przyjmowanie perspektywy borsuka, lisa, jelenia i wydry czy ptaka - jerzyka.

Autorzy tych prac, w celu jak najlepszego zrozumienia natury (tożsamości?) zwierząt, przyjmują ich perspektywę, próbując przekroczyć granicę między tożsamością człowieka a tożsamością nie-człowieka. Najbardziej radykalna z wymienionych, próba Fostera, okazała się nieudana - z perspektywy Levinasowskiego Innego wskazała, że zaprojektowany przez niego sposób poznania Innego jest niemożliwy, a wcielenie się w Innego pozostaje na zawsze niespełnionym życzeniowym projektem, który kończy się fiaskiem - nie ze względu na chęci (w zasadzie pomimo chęci), ale ze względu na fizjologiczne ograniczenia ustalające nieprzekraczalne granice pomiędzy gatunkami. Zbliżenie się do zwierzęcia jest tu więc próbą przekroczenia granicy pomiędzy ja i Inny. Z jednej strony obserwujemy oczywistą niemożność dokonania transgresji, a z drugiej - głęboko osadzone pragnienie poznania zwierzęcia i świata zwierzęcym sposobem poznawania. Recenzje oceniające tę popularyzatorską pracę koncentrują się na przymiotnikach typu „śmieszna, 
komiczna, zabawna”, ale w zasadzie praca ta jest tragiczna. Obnaża ludzką niemożność wczucia się w Inne zwierzę. Taka transgresja tożsamości nie może dojść do skutku. Foster pisze o pracy Bakera poświęconej sokołom: dostrzegał w niej deklaracje zarzucenia własnego ja, oddalenia się od ludzkiej tożsamości po to, by zrozumieć tożsamość ptaka (Foster 2017: 24). O swoim działaniu mówi zaś: „Moja metoda polega zatem na podejściu do tej granicy tak blisko, na ile to możliwe, i zajrzeniu za nią za pomocą wszystkich możliwych narzędzi” (Foster 2017: 25). Dalej komentuje, że jego próby przeistoczenia się w inne zwierzę (np. borsuka) boleśnie obnażyły niemożność wejścia w skórę innego zwierzęcia (Foster 2017: 78) - już choćby sama struktura i inna siła zmysłów u różnych gatunków uniemożliwia identyczne odbieranie świata. Na pozór trywialne spostrzeżenie: „Świat borsuka składa się w głównej mierze z zapachów” (Foster 2017: 79) ukazuje tę niemożność w całej prostocie, a jednocześnie trudności (związanej z tym, że zmysły tego zwierzęcia pracują zupełnie inaczej niż zmysły ludzi). I mimo że Foster próbuje za wszelką cenę zbliżyć się do zwierzęcego Innego (na przykład do borsuczej wizji świata, poprzez uczęszczanie na rozliczne warsztaty, ćwiczenia, szkolenia i praktyki wzmacniające i usprawniające węch), nigdy nie przejdzie na borsuczą stronę: „Chcę przez to powiedzieć, że sposób, w jaki nieuchronnie postrzegam i opisuję borsuczy świat zapachów, będzie zawierał elementy niemające żadnego odpowiednika w faktycznym życiu borsuka. Będą czysto ludzkim wytworem. To właśnie jest główne źródło nieautentyczności” (Foster 2017: 85). Okazuje się więc, że próba bycia tym zwierzęciem jest oparta na antropocentrycznym wyobrażeniu tego, jak to zwierzę żyje, i że w konfrontacji z warunkami preferowanymi przez człowieka wejście w prawdziwą skórę zwierzęcia nie jest możliwe. Jest to oczywiście w pierwszej kolejności ograniczenie narzucone przez konstrukcję psychofizyczną danego organizmu. Każdy z gatunków inaczej postrzega świat: nie tylko innymi zmysłami, ale też inną ich strukturą. Medium staje się przekazem, jak by powiedział Marshall McLuhan. Percepcja świata jest kształtowana przez funkcjonujący w nim organizm: „Wszystko to były symptomy paskudnej choroby, na którą wcześniej miałem nadzieję być uodporniony - kolonializmu” (Foster 2017: 78).

W swojej książce Foster (2017: 78) wprowadza pojęcie ekokolonializmu - genialne w swojej prostocie, a jednocześnie zaskakujące, oddające jednoznacznie rodzaj relacji łączący człowieka z jego biologicznym otoczeniem. Tak jak w przypadku pojęcia kolonializmu już na trwałe osadzonego w naukach o kulturze potrzebne było sformułowanie pojęcia relatywizmu kulturowego, tak i w przypadku ekokolonializmu jest 
zapewne potrzebne wprowadzenie analogicznego pojęcia relatywizmu ekologicznego. Miałoby ono zwracać uwagę na fakt, że istnieją inne biologiczne nisze niż nisza ludzka i że nie są one dostępne poznaniu ludzkiemu bez zastosowania charakterystycznych dla tych nisz biologicznych narzędzi funkcjonowania. Tak jak nie można według relatywizmu kulturowego opisywać innych kultur kategoriami charakterystycznymi dla kultury własnej, tak nie można nisz biologicznych innych gatunków zrozumieć bez wcielenia się $\mathrm{w}$ te gatunki. Jak zatem mamy poznawać świat przyrodniczy? Czy jest to w ogóle możliwe? Czy opisywanie tego świata językiem, pojęciami i kategoriami ludzi nosi znamiona imperializmu ekologicznego?

Idea wchodzenia w skórę borsuka, lisa czy innego zwierzęcia wydaje się na pozór naiwna i śmieszna, lub wręcz niedorzeczna. Jednak trudno w niej znaleźć komizm, szczególnie jeśli przyjąć rzeczywiście, że eksperyment Fostera ukazuje w całej rozciągłości niemożność poznania Innego. Jak w takim razie, idąc za filozofami dialogu, poznać siebie i swoje prawdziwe ja, kiedy jest ono zawsze stawiane w opozycji do Innego, a inny jest nieodgadniony? Czy ja pozostaje dla podmiotu na zawsze tajemnicą nie do odkrycia? To pytanie zyskuje na sile w obliczu dynamicznego mariażu człowieczeństwa z technologiami. Proces ten owocuje powstawaniem inteligentnych robotów, których możliwości wykraczają daleko poza dotychczasowe wizje. Już bowiem Innym jest nie tylko zwierzę nie-ludzkie. Ekstremalny eksperyment Fostera obnaża jednoznacznie fakt, że sama filozofia dialogu zaplanowana była z, być może nieuświadamianej, jednak głęboko uwewnętrznionej, antropocentrycznej perspektywy. Nie pozwala więc wyjść poza nią, przynajmniej jeśli chodzi o podmiotowość osób nie-ludzkich. Ten poważny dylemat - czy poznanie świata poza człowiekiem jest możliwe? - znajduje negatywną odpowiedź w pracy Fostera, który dochodzi do konkluzji, że obcość jest wpisana w ludzką tożsamość i że zawsze towarzyszy jej de facto niemożność porozumienia się z Innym. Tożsamość-autentyczność i obcość to pojęcia tworzące nierozłączną diadę. Bez elementu obcości nie sposób zachować autentyczną tożsamość. Zawsze musi ona mieć pierwiastek niezrozumiałości dla innych podmiotów. Zapewnia to autentyczność tejże tożsamości (Foster 2017: 331-332).

Czy zatem eksperymentowanie z tożsamościami ludzkimi i nie-ludzkimi jest skazane rzeczywiście na porażkę? Otóż sądzę, że nie. Po pierwsze, „nieudane” eksperymenty dostarczają wiedzy tak samo wartościowej jak eksperymenty udane. Wyzwaniem jest tylko odpowiednie wykorzystanie tejże wiedzy. Po drugie, eksperymenty w rodzaju tych, jakie przeprowadził 
Foster, wskazują niedoskonałość filozofii dialogu, rysując przed nią możliwość napisania kolejnego rozdziału obejmującego relacje z Innym, ale Innym nie-ludzkim. Po trzecie, omawiany typ eksperymentów poszerza sfery czucia (empatii, możności lub niemożności wcielenia się w innego), choć może w mniejszym stopniu przyczynia się do poszerzenia sfer wiedzy.

Współcześnie stawiane pytania o tożsamość podmiotu ludzkiego powinny wrócić do zagadnienia powiązania tożsamości z miejscem. Jak sugerowałam na początku niniejszego tekstu, przez jakiś czas zachwyceni globalizacją i możliwościami, jakie ona niesie ze sobą, odeszliśmy z miejsc, traktując je jako zbędne w definiowaniu i kultury, i tożsamości. Oba te fenomeny oderwane zostały do konkretnej lokalizacji w przestrzeni, między innymi za sprawą społeczno-regulacyjnej koncepcji kultury. Przesuwając kulturę z materialnie zdefiniowanej rzeczywistości w kierunku rzeczywistości myślowej, wskazujemy za Kmitą, że osadzenie w przestrzeni nie jest dla tożsamości konieczne. Kiedy jednak wracamy myślą do konfrontowania tożsamości podmiotu ludzkiego z nie-ludzkim, okazuje się, że ten drugi jest niesłychanie mocno zakorzeniony w miejscu. Jak w swojej kontrowersyjnej pracy pisał Foster (2017: 111-112): „Borsuki przynależą do miejsc i dlatego (a to «dlatego» jest niesamowicie istotne) je posiadają; jak mało które albo wręcz żadne inne zwierzę. Zamieszkujące wnętrza gór dynastie trwają dłużej od najbardziej odwiecznych, herbowych ludzkich rodów. [...] Borsuki są dla mnie ucieleśnieniem genius loci”.

W eksperymencie opisywanym przez Fostera na użytek przeciętnego „człowieka z ulicy” mamy do czynienia z projektem na pozór abstrakcyjnym i absurdalnym. W kontekście rozważań o nowych tożsamościach jest to jednak doświadczenie noszące znamiona projektu transgresyjnego. Zastanawiające jest to, że różni autorzy, na różnych poziomach refleksji podejmują próby ustalania, po pierwsze, gdzie dokładnie przebiega granica pomiędzy tożsamością ludzką a nieludzką, i po drugie, czy jest możliwe dokonywanie transgresji pomiędzy tymi tożsamościami. Doświadczenia te poniekąd są skazane na porażkę w tym sensie, że nie udaje się ustalić ani jednego, ani drugiego. Być może jednak dla doświadczających autorów tego rodzaju doświadczenie jest ważnym, potrzebnym do ustalenia swojego własnego ja elementem. Przekonanie się bowiem o tym, że tożsamość ludzka i nie-ludzka zazębiają się poprzez połączenie ich w środowisku przyrodniczym stanowiącym wspólny punkt odniesienia, jest ważnym doświadczeniem granicznym, ale też wskazuje na nierozerwalność oddzielanych dotąd kontekstów (mimo że konteksty te pozostają dla siebie tajemnicami). 
Sztuczny podział na to, co kulturowe i co naturalne, traci zupełnie sens, jeśli próbować ustalić między nimi granice. Należy sobie bowiem postawić wtedy pytanie, gdzie ta granica miałaby przebiegać. Gdzie kończy się środowisko naturalne, a gdzie zaczyna się środowisko kulturowe? Od którego historycznego momentu człowiek powinien być uznany za czynnik zakłócający biologiczny mir świata? W popularnonaukowej pracy Peter Wohlleben (2017: 195) pisze: „Ja sam widziałbym linię podziału w punkcie przejścia od myśliwych i zbieraczy do rolników. W tym miejscu zaczyna się celowa hodowla, a tym samym zmienianie gatunków, tu bierze początek świadome zmienianie krajobrazu i przekształcanie go w ekosystem całkowicie podporządkowany ludzkim potrzebom”. Ten „punkt przejścia” nie jest jednak przecież punktem, to długotrwały proces rozłożony w czasie. Na gruncie zaawansowanej refleksji na temat ciągłości natury-kultury wypowiadają się Bruno Latour (2009) czy Rossi Braidotti (2004).

Konkludując, współczesna rzeczywistość społeczna wymusza zmiany w myśleniu o procesach identyfikowania się, budowania tożsamości i o ich relacjach z otoczeniem. Nie sposób już dzisiaj rozdzielać tożsamości podmiotu ludzkiego od tożsamości nie-ludzkich. Ich związki są czytelne i niezaprzeczalne, a podkreślają to autorytety naukowe zarówno z obszaru humanistyki i nauk społecznych (Will Kymlicka), jak i ekologii i nauk przyrodniczych (Edward O. Wilson). Namysł nad tożsamością człowieka wymaga zintegrowania go z jego otoczeniem, którego nie można już dzielić na „kulturowe” i „naturalne”. Ostrość tych podziałów jest kwestionowana jako niemożliwa do konsekwentnego przeprowadzenia (gdzie bowiem przeprowadzić linię demarkacyjną dzielącą naturę od kultury?; od kiedy człowiek przestał funkcjonować w środowisku naturalnym, a zaczął tworzyć środowisko kulturowe?). Tego rodzaju zmiany na metapoziomie myślenia o tożsamości stawiają w zupełnie innym świetle zagadnienia, takie jak identyfikacja narodowa, definiowanie wspólnoty narodowej i obywatelstwa czy tożsamość regionalna. Zmienia to także myślenie o mobilności - przemieszczanie się człowieka nie oznacza odrzucenia potrzeb zakorzeniania w konkretnym miejscu. Przeciwnie - nasila i uwypukla tę potrzebę. Namysł nad przemianami życia codziennego ponowoczesnego świata zachodniego prowokuje do zupełnie innego definiowania obszarów nauk ścisłych i humanistycznych. Nie mówimy już o interdyscyplinarności, lecz tworzymy podejścia transdyscyplinarne. Wielokulturowość staje się zaś jednym z wymiarów różnorodności: bioróżnorodności w nowym sensie. 


\section{Literatura}

Baker J.A. (1967), The Peregrine, London: HarperCollins Publishers.

Banaszak G., Kmita J. (1994), Społeczno-regulacyjna koncepcja kultury, wyd. 2, Warszawa: Instytut Kultury.

Bauman Z. (1993), Ponowoczesne wzory osobowe, „Studia Socjologiczne” nr 2.

Bauman Z. (2000), Globalizacja, przeł. E. Klekot, Warszawa: PIW.

Bauman Z. (2004a), Identity. Conversations with Benedetto Vecchi, Cambridge: Polity Press.

Bauman Z. (2004b), Życie na przemiał, przeł. T. Kunz, Kraków: Wydawnictwo Literackie.

Braidotti R. (2004), Po człowiek, przeł. J. Bednarek, A. Kowalczyk, Warszawa: Wydawnictwo Naukowe PWN.

Erikson E.H. (2004), Tożsamość a cykl życia, przeł. M. Żywicki, Poznań: Zysk i S-ka Wydawnictwo.

Foster C. (2017), Jak zwierzę. Intymne zbliżenia z naturq, przeł. J. Konieczny, Poznań: Wydawnictwo Poznańskie.

Fukuyama F. (1997), Zaufanie. Kapitał społeczny a droga do dobrobytu, przeł. A. i L. Śliwa, Warszawa: Wydawnictwo Naukowe PWN.

Giddens A. (2002), Nowoczesność i tożsamość, przeł. A. Szulżycka, Warszawa: Wydawnictwo Naukowe PWN.

Kymlicka W. (1996), Multicultural Citizenship, Oxford: Oxford University Press.

Kymlicka W., Donaldson S. (2011), Zoopolis. A Political Theory of Animal Rights, Oxford: Oxford University Press.

Latour B. (2009), Polityka natury, przeł. A. Czarnacka, Warszawa: Wydawnictwo Krytyki Politycznej.

Mamzer H. (2002), Tożsamość w podróży, Poznań: Wydawnictwo Naukowe UAM.

Mamzer H. (2008), Poczucie bezpieczeństwa ontologicznego. Uwarunkowania społecznokulturowe, Poznań: Wydawnictwo Naukowe UAM.

Mamzer H. (2016a), Opór, nieposłuszeństwo i zaangażowanie obywatelskie, w: M. Durzewska, H.A. Kretek (red.), Obywatel w aspekcie fenomenologicznym, Racibórz: Wydawnictwo Państwowej Wyższej Szkoły Zawodowej w Raciborzu.

Mamzer H. (2016b), Społeczności lokalne a społeczeństwo obywatelskie, w: T. Herudziński, P. Swacha (red.), Społeczności lokalne wobec wyzwań współczesności, Warszawa: Wydawnictwo SGGW.

Mead M. (1978), Tożsamość i kultura. Studium dystansu międzypokoleniowego, przeł. J. Hołówka, Warszawa: Wydawnictwo Naukowe PWN.

Mowat F. (1997), Nie taki straszny wilk, przeł. R. Stiller, Warszawa: Prószyński i S-ka.

Mueller M.L. (2017), Being Salmon, Being Human: Encountering the Wild in Us and Us in the Wild, Chelsea: Green Publishing.

Thoreau H.D. (2011), Nieposłuszeństwo obywatelskie, w: idem, Życie bez zasad i inne eseje, przeł. H. Cieplińska, Poznań: Dom Wydawniczy Rebis.

Wilson E.O. (1984), Biophilia. The Human Bond with Other Species, Harvard: Harvard University Press. 
Wilson E.O. (2016), Znaczenie ludzkiego istnienia, przeł. B. Baran, Warszawa: Wydawnictwo Aletheia.

Wilson E.O. (2017), Pół ziemi. Walka naszej planety o życie, przeł. B. Baran, Warszawa: Wydawnictwo Aletheia.

Wohlleben P. (2017), Nieznane więzi natury, przeł. E. Kochanowska, Kraków: Wydawnictwo Otwarte.

\section{Źródła internetowe}

http://budzetyobywatelskie.pl [28.12.2017]

http://www.orlan.eu/ [1.01.2018]

https://www.youtube.com/watch?v=S5t6K9iwcdw [1.01.2018] 